\title{
Immune responses of preruminant calves fed antigenic soyabean protein
}

\author{
D Dréau 1,2, JP Lallès ${ }^{1}$, H Salmon 2 ${ }^{2}$ R Toullec ${ }^{1}$, JW Sissons ${ }^{3}$ \\ 1 INRA, Laboratoire du Jeune Ruminant, 65, rue de Saint-Brieuc, 35042 Rennes; \\ 2 INRA, Pathologie Infectieuse et Immunologie, 37380 Monnaie, France; \\ 3 Protein Technologies International, Saint Louis, MO, USA
}

It is well established that preruminant calves sensitized to soyabean protein develop specific humoral immune responses (Sissons, 1982). Although systemic cell-mediated immunity does not seem to be stimulated by antigen feeding (Heppell et al, 1987), there is no information on the possible implication of lymphocytes at the local (gut) level. An experiment was therefore designed to analyse celular aspects of this immune response.

Twelve calves were fed milk replacers $(58-60 \mathrm{~g}$ $\mathrm{DM} / \mathrm{kg}^{0.75} / \mathrm{d}$ ) containing skim-milk protein (SMP, $n=3$ ) or a mixture (3:7) of whey and either nonantigenic (NASP, $n=4$ ) or antigenic (ASP, $n=5$ ) soybean protein, from 1 to 4 months of age. Systemic anti-soya antibodies were assayed by passive haemagglutination. At slaughter, lymphocytes were isolated from the blood (PBL) and mesenteric lymph nodes (MLNL). Fresh cells were stimulated in vitro for $5 \mathrm{~d}$ with polyclonal mitogens or various proteins purified from soyabean.

As already observed (Sissons, 1982), calves fed the ASP diet had higher $(P<0.01)$ anti-soya antibody titres at the end of the trial (mean \pm SEM $9.3 \pm 0.5)$ than those consuming NASP $(1.0 \pm$ $0.7)$ and SMP (1.4 \pm 0.9$)$ diets. All the polyclonal mitogens tested (pokeweed mitogen, concanavalin A, lipopolysaccharide) were effective in inducing lymphocyte proliferation although PBL seemed to be less sensitive than MLNL cells (average stimulation index of $310 \pm 86$ and $20 \pm$ 7 for MLNL and PBL respectively, $n=12$ ). Generally low lymphoblastic transformation (overall stimulation index close to 2 on average) was observed when proteins purified from soyabean (glycinin, $\alpha$-conglycinin, $\beta$-conglycinin, soyabean agglutinin) were added at 2 levels ( 1 and $2.5 \mu \mathrm{g} / \mathrm{ml}$ ) to PBL and MLNL cultures regardless of dietary treatments. This is in agreement with the absence of delayed cutaneous hypersensitivity reactions to native soyabean proteins observed in sensitive calves (Heppell et al, 1987).

Therefore, it can be concluded that under our experimental conditions no significant lymphocyte activation by soyabean proteins was observed. Further tests should be carried out at different antigen concentrations before a conclusion can be drawn involving cellular mechanisms in the development of gut hypersensitivity reactions to dietary components in calves.

Heppell LMJ, Sissons JW, Stobo IJF, Thurston SM, Duvaux C (1987) In: Food Allergy (RK Chandra, ed) Nutr Res Ed Found St John's Newfoundland, 109-115

Sissons JW (1982) Proc Nutr Soc 41, 53-61 